\title{
Auperseedeby:
A A-187
}

D. S. Goological Survey

Anohorage, Alaska

PRELTMINARY REPORT ON GROUND-WATER CONDITIONS

AT HOMGR, ALASKA

By

Roger M. Wallor

Open-1110 report

1962 


\section{PRELTMINARY REPORT ON GROUND-WATER CONDITIONS}

AT HONSR, ALASKA

\section{By}

Roger M. Maller

\section{INTRODUCTION}

A ground-water study of the Homer area is being made during 1961-62 as a part of an investigation of ground-water resources of Alaska begun bJ the U. S. Geologioel Survoy in 1947. The purpose of the studies are to map the water-bearing formations and dotermine the occurrenoe, avallablitty, and quality of ground water in the state. The Homer ares has a water problem in regard to poor quality water and to rather limitod yield of wells (Coderstrom, Wahrhaftig, and Barnes, 1950, p. 4, and Coderstrom, 1952, p. 18-19). Manj homes rely on springs or shallow wolls whioh furnish a meager supply of poor quality water. This prellmInary report wes oomplled at the urgent request of the Homer Publio Utilities for planning a water utility. A Plnal roport on the investigation of the ground water and geology of the greater Homer ares is scheduled for complotion in 1962.

Work to date consists of a drilled-well inventory, water-level observations, partial spring inventory and geologio flold observations, and field determinations of the lron content of well and stream vater. Data representing over 100 wells have been tabulated as to location, dopth, jiold, roportod quality, and topographic situation. This roport summerizes the tentative conclusions on the occurrence and avallability of ground water. Offloe compilations of a well-location map, well logs, and chomioal analyses of wator in the arou aro avallable at Anchorago for consultation by interosted partios for planning vater improvements.

\section{COSOLOY}

The Homer aree is underlein by sedimentary rooks of the Konai Tormation of Tertiery age, which is oonsidered to be of fresh-water origin (Smith, 1939, p. 61). A recent Investigetion of the coal resources prosent in the Konal Formation (Barnes and Cobb, 1959) shows that "The Ronal formation consists of moderately indurated sand, s1lt, and clay in generally thin and intergrading bods and lonses, interbodded with a fow thin lenses of fine oonglomerate and many beds of subbituminous and 11 gnitio coel ranging from fow inches to 7 peot in thiokness. Ferruginous masses in thiok sandstone bods, and ironstone 
concretions, in distinot bands and as scattered nodules, are common throughout the formation **" The thickness of the formation at Homer is unknown, but it is probably on the order of several thousand feot.

The structure of the Konal Formation at Homer is summarized by Barnes and Cobb (1959, p, 227) as "Wolng characterized by broad, gentle folds in which the dips are generally loss than $10^{\circ}$, and by high-angle faults with vertical displacoments ranging from a fow inches to noarly 80 feet. . The general trond of the fold axes appear to be to the northeast, and the faults, with a for exceptions, strike northwestward."

Most of the Hower aree is mantled with unconsolidated silt, sand, or gravel to depths ranging from a fow inohes to at least one hundred foot. The meterial represents glacial, alluvial, colluvial, and windblown silt deposits. Several feet of peat covers much of the land at the base of the Homer escarpment.

The surficial deposits are related to glaciation. Glaciers moved westward, from the Kenai Mountains, dow Kachewak Bay and probably coolesced with gleciers moving south down Cook Inlot and aoross the Kenet Peninsul lowland. The glaciers and associated molt-water streams left thin, predominately silty olay doposits overlying the Tertiary bedrook. Below about the 150-foot elevation contour (approximates the main roed through homer), the surficial material becomes thicker as noted in boaoh bluffs (50 feot or more) and reoorded in well logs (about $100 \mathrm{fo \theta t}$ ). Unverified information from selsmio orews drilling on the Homer Spit indicates that unconsolldated sediments over 300 feot thiok occur there. Drillers' interpretation of the "moderately indursted" Kenal Formation versus glaciofluvial deposits are questionable, however. The spit is tentatively considered to represent a reworked terminal moraine deposit athwart the bay, with a maximum thicloness (based on Kaohemak Bay soundings) of about 500 feet at the end of the spit.

\section{GROUND WATTR}

\section{Ocourrence}

Ground water is derived by infiltration into the earth from rain, from the melting of snow, and from surface bodies of water. The water moves downward through the soll and permeablo rook unt1l it reaches the vater tablo. It then migrates laterally to lowor parts of the satureted zone until it is discharges naturally through seops and springs into streams or lakes, or by evaporation, or by transpiration of plants. Artificial discharge may tako placo from vells constructod into the water-boaring zono. 
Fine-grained material inhibits downard and lateral migration of the ground water. Dense meterial, such as clay, restricts ground-water movement and causes the water to build up behind or above it and create a perched water table. Many springs, lakes, and swamps may be formed in this manner.

\section{Bedrock aquifers}

Most of the wells in the Homer area obtaln water from permeable zones in the Kenal Formation at depths of 50 to 200 feet. The waterbearing zones oocur in fine- to medium-grained sandstones and in freotured ooal beds. Studios to date do not indicate that any partioular aquifer exists over a large aroa. On the basis of the study by Barnos and Cobb (1959) the formetions should be falrly untform in any one area and hence, the equifers would be consistent also. However. 100 al variations in the permeability of the sandstone and coal beds are thought to create the apparent laok of areal extent of the aquifers.

In general, water-bearling sandstone or oon beds are enoountered alcost anywhere in the area. The ground water moves laterally through the permeable sandstones and the fractured coal beds overlying silts tone or "undercley" (beneath ooal beds) which inhibits downward movement. Hence, the water-bearing zones probably are numerous and not necesserily interconnected. The strike of the Kenal Formation along the Homer esoarpment, generally mantled by the thin unoonsolidated material. creates many springs as the ground water emerges from its "perohed" condition over each impermeable layer. These springs are prominent in the numerous gulleys or canyons out into the esoarpment, where they flow over or out of the coal beds. Farther down the slope, where the surficial material mantles the bedrook, probably the same type of groundwater movement occurs, but the water is dissipeted through the thin mantio croating a very wot condition. Many homes are tapping water from this souroe, elther as an improved "spring" or as a dug well.

The jields of wells in the Kenal Formation aquifers are poorly known. Very fow of the drilled wells have been tested for susteined yleld. One well which supplies several homes, businesses, and the sohool system has a reported capacity of 50 gallons per minute (gpm) at 120 foet of drawdown. The woll oasing is perforetod from 30 to 37 foet and 98 to 165 feot belo the land surface. Two deop (500-600 foet) wells of comparable ylold heve been drilled at the top of the 1,000-foot osoarpment, outside the aroa of this preliminary report. One of these wells has supplied over 10,000 gallons per day for several years. Neither of these wolls tap the equifers encountered in Homer wells. Elsewhore in the vicinity of Homer, the 6-1nch, cased, open-end wells have an average roported yield of about $9 \mathrm{gpm}$ as based on the driller's bailer tests. 


\section{Unconsolidated sand and gravel aquifers}

Several wells have been drilled into the several tens of foet of glaciofluvial deposits in the lower part of the Homer area and have encountered water in sand or gravel, Based on the drillers' logs, the water-bearing formations were inedequate for well completion. These wells generally oncountered a water-bearing zone, yielding enough water for domestio or commerolal use, at whet appears to be the bese of the surficial deposits or the top of the underlying Renal Formation.

It appoars that no extensive aquifer in the surficial deposits hes been encountered to date. About 8 wells on the low bench south of Beluge Lake obtain water in Iimited quantitios from this material. however.

\section{Quality of water}

Water in the Homer area is distinguished by the relatively high content of iron, up to 25 parts per million ( $\mathrm{ppm})$. Dissolved solids content of ground water is moderate with a range of $100-350 \mathrm{ppm}$, although one well showed $979 \mathrm{ppm}$. Generally, silioe, calolum, and bicarbonate are the largest constituents.

As part of the current investigation, fleld determinations of the iron content of water from most of the small streams flowing off the escarpment were made. In addition, two stroam systems were checked in detail for iron content. It was thought that such determinations mlght delineate souroes of iron-bearing water from seops or springs. The study wes made in May at a time whon most of the streamflow was considered derlved from springs and ground-water seepage.

Tentative conclusions besed on stream-water enelyses, point toward the Eest HIll Road area as an area of botter quality (less than $2 \mathrm{ppm}$ 1ron) ground water. Sampling of vaters to determine iron content is planned to oonfirm this possibility. The fow well-water anelyses on hand before the investigetion indicate thet $108 s$ fron is present in wells ebove Homer than those on the lower and far east slopes.

\section{WATER UTILIZATION}

\section{Current use}

Two wells at Homer are considered es semipublio supply wells. The Homer Water Company well is estimeted to supply about 3,000 gallons per day (gpd) during the school term. The Soroggs well probably supplies about 4,000 gpd. Approximately 90 other drilled wells in the area are principally domestic wells and probably are pumped less than 200 gpd. Totel ground-water utilization, including springs, at Homer is roughls estimated to be about $50,000 \mathrm{gpd}$. 


\section{Ground water for future development}

Preliminary results of the investigation indicate that ground water is available from the Konal Formation in small to moderato quantitios and of gonorally good quality exoept for high-iron content in most areas. Potable domestic supplios are apparently difficult to obtain because of the high-iron content which precludes a simple inexpensive treatment. Obtalning public supplies appoars foasible by the construction of two or more large diameter wells screaned or perforated opposite water-beering zones, properly developed, and spaced more than a fow hundred foet apart to prevent drawdown interferenoe while purnping. Water treatment, espeoialiy for 1ron content, will bo necessary. Test drilling in spectfic areas prior to developing a public supply should be undertaken. Careful records should be kept of each well drilled, acourate sampling of water from each horizon is imperative to delineate water of infortor quelity (partioularly iron), and a properly conducted pumping test should be made to determine the yield. For the sake of economy, a properly constructed successful test well may be converted to a production well.

The geologic and hydrologic conditions of the area polnt out an alternate means of obtaining public-water supplios whioh is succossful in some areas. The successive water-bearing zones of the northwarddipping Konai Formation make it foesible for the construction of a tunnel into the esoarpment to intercept the vater.

Som advantages of this typo of supply are:

1. Greater amount of water avallable than from a single voll souroe.

2. Construction at an elevation above $300(?)$ foet would croate a gravity supply.

3. A tunnel source would provide air to the water whioh should remove much of the iron by oxidation.

4. The tunnel could act as a reservolr by installing a bulkhead at the tunnel entrance.

5. The supply oould easily be increased by extension of the tunnel or constructing drifts along water-bearing zones.

6. Construction by local means is foestble. Experience and foasibility may be gained from former ooal-mine operations in the area. 
Some disedvantages of the tunnel method are:

1. Initial costs may be high for excavation and lining (perforeted) the tunnel to provent cave-ins.

2. Site of tunnel should be cored or drilled (extra cost) to make sure an impermeable "dry" section is not present.

3. Perlodic cleaning of the tunnel probably would be necessary.

\section{References cited}

Barnes, F. F., and Cobb, E. H., 1959, Gology and coal resources of the Homer District Konal coal fiold, Alaska: U. S. Gool. Surver Bull. 1058-T, p. 217-260.

Cederstrom, D. J., 1952, Summary of ground-water development in Alaska, 1950: U. S. Geol. Survey Circ. 169, 37 p.

Coderstrom, D. J., Wahrhaftig, C., and Barnes, F. F., 1950, Ground water in the vioinities of Healy and Homer, Aleska: U. S. Geol. Survey open-file report, 4 p. 